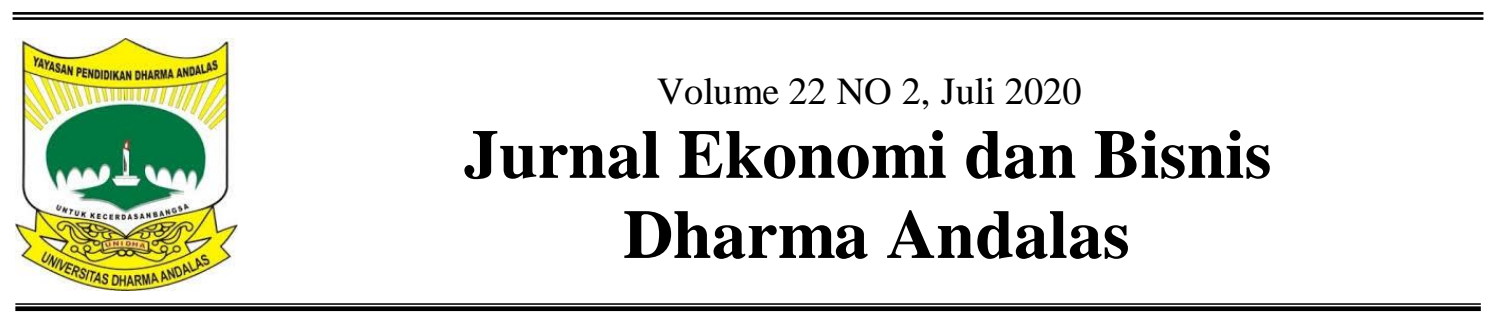

\title{
Implementasi Financial Projection Sebagai Strategi Pengelolaan Keuangan
}

\author{
Nur Anna ${ }^{1}$, Syamsul Ridjal ${ }^{2}$, Herman Sjahruddin ${ }^{3}$ \\ Sekolah Tinggi Ilmu Ekonomi Makassar Bongaya ${ }^{1,2,3}$ \\ email: nuranna546@gmail.com ${ }^{1}$
}

\begin{abstract}
This research was conducted to analyze the implementation of financial projections as a financial management strategy at PT. PLN (Persero). The population of this study is the financial statement of PT. PLN (Persero) 2014-2018. Sampling was carried out using purposive sampling method. The sample used was 5 years of financial statement. The data analysis method used is quantitative descriptive analysis technique, which is an analysis that describes by calculating the company's financial projections report using certain formulas. Financial projection indicators used in this study use growth rate method to determine sales projections and common size analysis to determine the project balance sheet and income statement. Based on the results of the study showed an increase in sales projection of $16 \%$, as well as balance sheet and income projections which both experienced an increase of $18 \%$ for the projected balance sheet and 5\% for the profit and loss projection.
\end{abstract}

Keywords: financial projection, sales growth rate, common size analysis

\begin{abstract}
ABSTRAK
Penelitian ini dilakukan untuk menganalisis implementasi financial projection sebagai strategi pengelolaan keuangan pada PT. PLN (Persero). Populasi dari penelitian ini adalah laporan keuangan PT. PLN (Persero) Tahun 2014 - 2018. Penarikan sampel yang dilakukan menggunakan metode purposive sampling. Sampel yang digunakan sebanyak 5 tahun laporan keuangan. Metode analisis data yang digunakan adalah teknik analisis deskriftif kuantitatif, yaitu suatu analisis yang mendeskripsikan dengan cara menghitung laporan proyeksi keuangan perusahaan menggunakan rumus-rumus tertentu. Indikator financial projection yang digunakan dalam penelitian ini menggunakan metode tingkat pertumbuhan untuk mengetahui proyeksi penjualan dan analisis common size untuk mengetahui proyeksi neraca dan laba rugi. Berdasarkan hasil penelitian menunjukkan peningkatan pada proyeksi penjualan sebesar $16 \%$, begitu pula dengan proyeksi neraca dan laba rugi yang sama-sama mengalami peningkatan sebesar $18 \%$ untuk proyeksi neraca dan 5\% untuk proyeksi laba rugi.
\end{abstract}

Kata Kunci : financial projection, pertumbuhan penjualan, common size

\section{PENDAHULUAN}

PT. PLN (Persero) merupakan milik Negara yang berada dalam bidang sumberdaya listrik dan energi yang diperuntukkan bagi masyarakat indonesia. Kebutuhan BBM untuk PT. PLN (persero) saat ini merupakan yang terbanyak untuk di sektor industri yang dilayani secara langsung oleh PT. Pertamina, operasional pasokan BBM untuk PT. PLN (persero) didukung melalui 97 Terminal BBM milik

Pertamina yang tersebar dari Sabang sampai Merauke. Akibat tingginya biaya, PT. PLN (Persero) mencatat kerugian Sebesar RP 18,48 triliun untuk 
kinerja kuartal III 2018. Kerugian itu terjadi karena terus melemahnya nilai tukar rupiah terhadap dolar AS dan naiknya harga bahan bakar. Beban terbesar masih berasal dari beban bahan bakar dan pelumas yang naik dari Rp 85,28 triliun menjadi Rp 101,88 triliun. Perusahaan juga menderita pembengkakan kerugian karena selisi kurs, jika pada kuartal III 2017 rugi dari selisi kurs mencapai $\mathrm{Rp} 2,23$ triliun, maka pada kuartal III 2018 menjadi RP 17,33 triliun. (https://www.cnbcindonesia.com, diunduh pada 26 Februari 2020). Pernyataan tersebut menunjukkan menurunya kinerja keuangan PT. PLN (Persero). PT. PLN (Persero) Mengalami penurunan hal ini ditunjukkan dengan perolehan laba bersih perusahaan yang menurun, Laba bersih merupakan jumlah pendapatan setelah dikurangi biaya-biaya diluar HPP. Dengan kata lain laba bersih mengukur jumlah laba yang tersisa dalam bisnis setelah semua biaya telah dibayarkan dalam satu periode. Hasil tersebut dapat berubah seiring dengan meningkatnya produktivitas usaha perusahaan. Fakta empiris yang diperoleh dari laporan keuangan perusahaan menunjukkan fluktuasi pada laporan laba bersih, ditunjukkan pada tabel berikut:

Tabel 1

Laba bersih PT. PLN (Persero) Periode 2014-2018

\begin{tabular}{ccc}
\hline Tahun & Laba bersih & Perubahan \\
\hline 2014 & $11,069,30$ & - \\
2015 & $6,026,507$ & $-5,042,863$ \\
2016 & $8,150,383$ & $2,123,876$ \\
2017 & $4,428,115$ & $-3,722,268$ \\
2018 & $11,575,756$ & $7,147,641$ \\
\hline $\bar{X}$ & $8,250,026$ & 101,277 \\
\hline
\end{tabular}

Sumber: PT. PLN (Persero) (data diolah, 2020)
Pengelolaan keuangan yang dilakukan perusahaan membutuhkan strategi dalam pelaksanaannya demikian yang dilakukan PT. PLN (Persero) yang telah menyiapkan strategi untuk menjaga keuangannya yaitu dengan revaluasi aset, meningkatkan produktivitas aset yang sudah ada, efisiensi operasi dan pengadaan barang dan jasa. Meskipun demikian dalam menghadapi berbagai perubahan lingkungan dan kondidi kompetisis yang semakin meningkat perusahaan juga harus dapat merumuskan perencanaan yang tepat. Oleh karena itu pengukuran kinerja yang hanya dari perspektif keuangan tidaklah memadai lagi sehingga dibutuhkan strategi pengelolaan keuangan yang tepat untuk di masa yang akan datang.

Perencanaan bisnis terdapat beberapa penyesuaian, perlu identifikasi faktor keberhasilan dan kegagalan yang dapat digunakan dalam perencanaan mendatang. Dengan memproyeksikan kondisi keuangan Sebagai landasan strategis bagi direksi beserta jajarannya dalam menjalankan operasional perusahaan yang nantinya digunakan sebagai acuan dalam penyusunan rencana kerja dan perencanaan pengelolaan keuangan di masa yang akan datang. Financial projection merupakan proyeksi keuangan yang dirancang untuk penyelenggaraan sebuah usaha bisnis yang akan dijalankan maupun untuk pengembangan bisnis yang sudah berjalan (Wulandari, 2016:2).

Financial projection dilakukan oleh PT. PLN (Persero) Dengan alasan agar perusahaan tidak lagi mengalami kerugian. dan dapat mengantisipasi perubahan yang akan terjadi untuk beberapa tahun mendatang. Financial projection (Proyeksi keuangan) merupakan bentuk dari perencanaan keuangan yang bertujuan untuk menghindari perusahaan dari kerugian keuangan. karena proyeksi akan 
memudahkan perusahaan melihat apa yang akan terjadi pada beberapa tahun mendatang (Wulandari, 2016).

Financial projection pada penelitian yang dilakukan banyak peneliti terdahulu melakukan dengan menggunakan tiga komponen laporan keuangan yaitu: Pertumbuhan penjualan, Neraca, dan Laba rugi . Pertumbuhan penjualan menunjukan sejauh mana perusahaan dapat meningkatkan penjualannya dibandingkan dengan total penjualan secara keseluruhan (Kasmir, 2012). Pernyataan tersebut didukung oleh temuan peneliti terdahulu yang dilakukan (Rianti, 2014; Wulandari N., 2015; Wulandari, 2016; Arifin, 2018) menunjukkan bahwa financial projection pada laporan pertumbuhan penjualan mengalami peningkatan pada perusahaan untuk masa yang akan datang.

Neraca adalah ringkasan posisi keuangan perusahaan pada tanggal tertentu yang menunjukkan total aktiva dengan total kewajiban ditambah total ekuitas pemilik (James C Van Horne; dalam kasmir, 2015:30). Hasil penelitian terdahulu yang dilakukan (Anjasmara, 2012; Ranti, 2014; Arifin, 2018; Permana, 2019) menunjukkan bahwa financial projection pada laporan Neraca mengalami peningkatan pada perusahaan untuk masa yang akan datang.

Selain pertumbuhan penjualan dan neraca terdapat pula laporan keuangan lainnya yaitu laporan Rugi laba, Laporan laba rugi merupakan laporan keuangan yang mengambarkan hasil usaha perusahaan dalam suatu periode tertentu (kasmir, 2015:29), hasil penelitian terdahulu yang menunjukkan financial projection pada laporan laba rugi dilakukan (Enda, 2013; Ranti, 2014; Wulandari N, 2015; Wulandari, 2016; Arifin, 2018; Permana, 2019), yang menunjukkan hasil yang meningkat pada laporan laba rugi perusahaan untuk masa yang akan datang.
Mengacu pada hasil penelitian terdahulu yang memperoleh hasil yang meningkat atas penerapan proyeksi keuangan pada beberapa laporan keuangan, sehingga dari hasil tersebut dapat memberikan informasi perkembangan perusahaan yang akan mempengaruhi keputusan investor atau pihak yang berkepentingan dalam menilai tinggi rendahnya kinerja perusahaan. Temuan tersebut relevan dengan teori signal (signalling theory) yang dipelopori Ross (1977) Secara umum, sinyal diartikan sebagai isyarat yang dilakukan oleh perusahaan (manajer) kepada pihak luar (investor). Sinyal tersebut dapat berwujud berbagai bentuk, baik yang secara langsung dapat diamati maupun yang harus dilakukan penelaahan lebih mendalam untuk dapat mengetahuinya. Apapun bentuk atau jenis dari sinyal yang dikeluarkan, semuanya dimaksudkan untuk menyiratkan sesuatu dengan harapan pasar atau pihak eksternal akan melakukan perubahan penilaian atas perusahaan. Artinya, sinyal yang dipilih harus mengandung kekuatan informasi (information content) untuk dapat merubah penilaian pihak eksternal perusahaan (Tatang A Gumanti, 2015).

Mengacu pada latar belakang yang telah diuraikan, maka permasalahan penelitian ini apakah financial projection atas pertumbuhan penjualan, laporan neraca mengalami peningkatan dan apakah strategi financial projection dapat digunakan sebagai strategi pengelolaan keuangan pada PT. PLN (Persero) di masa yang akan datang?

Manajemen keuangan merupakan suatu proses dalam kegiatan keuangan perusahaan yang berhubungan dengan upaya untuk mendapatkan dana perusahaan serta meminimalkan biaya perushaan dan juga upaya pengelolaan keuangan suatu badan usaha atau organisasi untuk dapat mencapai tujuan 
keuangan yang telah ditetapkan. Manajemen keuangan berhubungan denga tiga aktivitas yaitu penggunaan dana, perolehan dana dan pengelolaan aktiva (Husnan, 2014:69)

Laporan keuangan merupakan laporan yang menunjukkan kondisi perusahaan saat ini atau dalam suatu periode tertentu. Kondisi perusahaan terkini maksudnya adalah keadaan keuangan perusahaan pada tanggal tertentu (neraca) dan periode tertentu (untuk laporan laba rugi) (kasmir, 2015:7).

Neraca adalah sebuah daftar aktiva dan kewajiban organisasi pada saat tertentu. Selisi antara akitiva dan kewajiban disebut ekuitas. Modal dapa dikatakan sebagai aktiva yang dimiliki oleh pemilik organisasi yaitu jumlah yang akan tersisa jika seluruh kewajiban dibayar. Neraca adalah pernyataan dari persamaan akuntansi dasar : Aktiva = kewajiban + Ekuitas Pemilik (Earl K, Stice, dkk, 2004 : 136; dalam Enda, $2013: 14$ ).

Laporan laba rugi (income statement) yang sering juga disebut statement of income atau statement of earning adalah laporan yang mengukur keberhasilan operasi perusahaan selama periode tertentu. Laporan laba rugi menyediakan informasi yang diperlukan oleh para investor dan creator, untuk membantu mereka memprediksi jumlah, penetapan waktu, dan ketidakpastian dari arus kas masa depan. (Kieso, et al, 2007:140; dalamSyafitri, 2014:31)

Pada dasarnya setiap laporan keuangan yang dibuat sudah pasti memiliki tujuan tertentu. Dalam praktiknya terdapat beberapa tujuan yang hendak dicapai, terutama bagi pemilik usaha dan manajemen perusahaan. Disamping itu tujuan laporan keuangan disusun guna memenuhi kepentingan berbagai pihak yang berkepentingan berbagai pihak yang berkepentingan terhadap perusahaan. Secara umum laporan keuangan bertujuan untuk memberikan informasi keuangan suatau perusahaan, baik pada saat tertentu maupun pada periode tertentu. (Kasmir, 2015:10)

Strategi dalam lingkup organisasi merupakan sebuah proses perencanaan, penetapan tujuan, serta penentuan sasaran kegiatan dalam jangka waktu yang juga ditentukan untuk mencapai segala sesuatu yang diharapkan oleh organisasi. Strategi merupakan penetapan sasaran dan tujuan jangka panjang suatu perusahaan atau organisasi dan alokasi sumber daya untuk mencapai tujuan. Strategi diartikan juga sebagai suatu rencana kegiatan yang menyeluruh yang disusun secara sistematis dan bersifat umum, digunakan dalam mencapai tujuan yang telah ditetapkan, harus dirahasiakan dan tidak semua orang dapat mengetahuinya. (Alfred Chandler, dalam Firdaus, 2016:17).

Kunci utama dalam proses perencanaan perusahaan adalah ramalan penjualan. Berdasarkan pendapat (Barry Render dan Jay Heizer, 2015) Peramalan (forecasting) adalah suatu seni dan ilmu pengetahuan dalam memprediksi peristiwa pada masa yang akan datang. Peramalan akan melibatkan mengambil data historis (seperti penjualan tahun lalu) dan memproyeksikan mereka ke masa yang akan datang dengan model matematika.

Laporan keuangan performa merupakan teknik untuk memproyeksikan kondisi keuangan untuk masa mendatang. Pada umumnya laporan keuangan proforma mempunyai dua tujuan (Falikhatun dan Putri N, 2007:40) yaitu:

a. Menganalisis kondisi keuangan perusahaan masa lalu dan masa sekarang.

b. Memproyeksikan kondisi keuangan (prestasi dan posisi keuangan) perusahaan pada masa mendatang. 
financial projection merupakan proyeksi keuangan yang dirancang untuk penyelenggaraan sebuah usaha bisnis yang akan dijalankan maupun untuk pengembangan bisnis yang sudah berjalan. Proyeksi laporan keungan merupakan sebagian dari proses perencanaan perusahaan yang mana perusahaan menempatkan aktivitas perusahaan dimasa depan yang berkaitan dengan ketidakpastian lingkungan ekonomi. Dengan adanya proyeksi keuangan diharapkan perusahaan tidak mengalami kerugian dan dapat mengantisipasi perubahan yang akan terjadi untuk beberapa tahun mendatang (Wulandari, 2016:2).

Beberapa Tahapan yang digunakan dalam perencanaan proyeksi laporan keuangan (Brigham dan Houston, 2006; dalam Arifin, 2018) yaitu dilakukan dengan menggunakan :

\section{Metode Tingkat pertumbuhan penjualan \\ Memproyeksikan penjualan pada} periode akuntansi, dilakukan dengan metode tingkat pertumbuhan penjualan selama lima tahun. Dari hasil perhitungan tingkat pertumbuhan penjualan tahunan, dihitung dengan tingkat pertumbuhan rata-rata yang nantinya akan digunakan untuk memproyeksikan nilai penjualan yang akan di proyeksikan atau tahun masa depan. Adapun rumus yang digunakan untuk mengitung tingkat pertumbuhan penjualan (Kasmir, 2012) adalah:

\section{Dimana :}

$$
\mathrm{Gt}=\frac{\mathrm{St}-\mathrm{S}_{\mathrm{t}-1}}{\mathrm{~S}_{\mathrm{t}-1}}
$$

$\mathrm{Gt}=$ tingkat pertumbuhan penjualan

St $=$ penjualan pada tahun $\mathrm{t}$

$S_{t-1}=$ penjualan pada tahun $\mathrm{t}-1$

Kemudian

$$
\mathrm{CAGR}=\left(\frac{\text { Nilai akhir }}{\text { Nilai awal }}\right)^{\left(\frac{1}{\text { jumlah tahun }}\right)}-1
$$

\section{Analisis Common size}

Common size analysis menganalisis laporan keuangan untuk satu periode tertentu dengan cara membanding-bandingkan pos yang satu dengan pos la innya. Perbandingan tersebut dilakukan dengan menggunakan presentase dimana salah satu pos ditetapkan patokan 100\% (Djarwanto, 1999; dalam Farida dkk, 2019) . Analisis common size terbagi atas laba rugi dan neraca, adapun rumus analisis common size yang digunakan untuk memproyeksikan laba rugi dan neraca adalah:

a. Memproyeksikan laporan laba rugi pada tahun yang akan di proyeksi yaitu dengan menggunakan analisis common size disusun dengan jalan menghitung tiap-tiap rekening dalam laporan laba rugi menjadi proporsi dari total penjualan. Adapun rumus laba rugi dalam common size yang digunakan (Djarwanto, 1999; dalam Farida dkk, 2019) adalah :

$$
\text { Laba rugi }=\left(\frac{\text { item dalam laba rugi }}{\text { total penjualan }}\right) \times 100 \%
$$

Kemudian

Proyeksi Laba Rugi=common size $\mathrm{X}$ proyeksi penjualan

b. Untuk memproyeksi neraca pada tahun yang di proyeksikan metode yang digunakan sama yaitu common size, setiap item dari neraca proforma dibagi dengan jumlah total aktiva untuk menghasilkan proporsi, dari hasil proporsi tersebut dikali dengan proyeksi total aktiva untuk menghasilkan proyeksi laporan neraca tahun yang diproyeksi. Adapun rumus yang neraca common size yang digunakan (Djarwanto, 1999; dalam Farida dkk, 2019) adalah:

$$
\text { Neraca }=\left(\frac{\text { item dalam neraca }}{\text { total aktiva }}\right) \times 100 \%
$$

Kemudian

Proyeksi Neraca $=$ common sizeXproyeksi total aset 


\section{METODE PENELITIAN}

Penelitian ini adalah penelitian analisis deskriptif menggunakan metode pendekatan kuantitatif. Pada Penelitian kuantitatif digunakan dengan desain penelitian cross sectional. Pendekatan cross sectional merupakan jenis penelitian yang dilakukan dengan cara mengumpulkan data pada satu waktu yang sama selama satu periode hari, minggu atau bulan, (susanto, $2013: 67$ ).

Jenis data yang dipergunakan adalah data kuantitatif. Data kuantitatif adalah jenis data yang dapat diukur atau dihitung secara lansung yang berupa informasi atau penjelasan yang dinyatakan dengan bilangan atau dalam bentuk angka. (Sugiono, 2010:15). Sumber data yang dibutuhkan dalam penelitian ini adalah data sekunder, yang diperoleh dari publikasi Laporan Keuangan yang diterbitkan.

Teknik yang dipergunakan dalam pengumpulan data dalam penelitian ini adalah metode dokumentasi yaitu teknik yang dilakukan dengan cara mengumpulkan, mencatat, dan mengkaji data sekunder yang berupa laporan keunangan perusahaan PT. PLN (Persero) melalui website www.pln.co.id serta dari berbagai referensi pendukung.

Variabel penelitian menggunakan variabel mandiri dimana financial projection sebagai variabel independen sekaligus variabel dependen.

\section{HASIL DAN PEMBAHASAN}

\section{Metode Tingkat Pertumbuhan penjualan}

Memproyeksikan penjualan pada periode akuntansi, dilakukan dengan metode tingkat pertumbuhan penjualan selama lima tahun. Dari hasil perhitungan tingkat pertumbuhan penjualan tahunan, dihitung dengan tingkat pertumbuhan rata-rata yang nantinya akan digunakan untuk memproyeksikan nilai penjualan yang akan di proyeksikan atau tahun masa depan. Adapun rumus yang digunakan untuk mengitung tingkat pertumbuhan penjualan (Kasmir, 2012) adalah:

$$
\mathrm{Gt}=\frac{\mathrm{St}-\mathrm{S}_{\mathrm{t}-1}}{\mathrm{~S}_{\mathrm{t}-1}}
$$

$$
\begin{aligned}
2015= & \frac{2015-(2015-2014)}{(2015-2014)} \\
& \frac{209,844,541-(209,844,541-186,634,484)}{(209,844,541-186,634,484)} \\
& \frac{209,844,541-(23,210,057)}{(23,210,057)} \\
& \frac{186,634,484 / 23,210,057}{8,041}
\end{aligned}
$$

Berdasarkan dari perhitungan tersebut maka diperoleh hasil untuk tahun:

$$
\begin{aligned}
& 2015=8,041 \\
& 2016=48,854 \\
& 2017=6,599 \\
& 2018=14,598
\end{aligned}
$$

Kemudian untuk memperoleh tingkat pertumbuhan rata-rata digunakan rumus

$\begin{aligned} \text { CAGR }= & \left(\frac{\text { Nilai akhir }}{\text { Nilai awal }}\right)^{\left(\frac{1}{\text { jumlah tahun }}\right)}-1 \\ & \left(\frac{8,041}{14,598}\right)^{\left(\frac{1}{4}\right)}-1 \\ & (1.815446)^{(4)}-1 \\ & 1.1607-1 \\ & 0.1607 \text { atau } 16 \%\end{aligned}$

Hasil perhitungan tersebut maka diperoleh proyeksi penjualan pada masa yang akan datang sebesar 16\%. Dengan demikian dapat dinyatakan financial projection pada pertumbuhan penjualan mengalami peningkatan sebesar $16 \%$ pada masa yang akan datang.

2018 (Nyata) 263,477,551

$2019 \quad 305,633,912.76 \quad(16 \%)$

(Proyeksi)

\section{Analisis Common Size}

Common size analysis adalah menganalisis laporan keuangan untuk satu periode tertentu dengan cara 
membanding-bandingkan pos yang satu dengan pos lainnya. Perbandingan tersebut dilakukan dengan menggunakan presentase dimana salah satu pos ditetapkan patokan 100\% (Djarwanto, 1999; dalam Farida dkk, 2019) .

\section{Neraca}

Perhitungan analisis common size pada laporan neraca PT. PLN (Persero) adalah sebagai berikut:

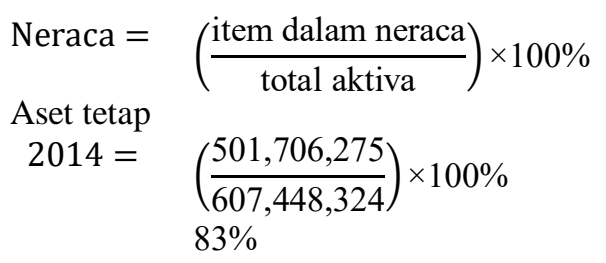

Berdasarkan perhitungan tersebut digunakan rumus yang sama untuk tiaptiap item dalam neraca untuk menentukan analisis common sizenya. Dinyatakan dalam hasil sebagai berikut:

Tabel 2

Neraca common size 2014-2018

\begin{tabular}{|c|c|c|c|c|c|c|}
\hline Catatan & 2014 & 2015 & 2016 & 2017 & 2018 & $\bar{X}$ \\
\hline \multicolumn{7}{|l|}{ ASET } \\
\hline \multicolumn{7}{|c|}{ ASET TIDAK LANCAR } \\
\hline Aset tetap & $83 \%$ & $90 \%$ & $90 \%$ & $90 \%$ & $90 \%$ & $89 \%$ \\
\hline $\begin{array}{l}\text { Aset pajak } \\
\text { tangguhan }\end{array}$ & $1 \%$ & $2 \%$ & $1 \%$ & $1 \%$ & $1 \%$ & $1 \%$ \\
\hline $\begin{array}{l}\text { Rekening } \\
\text { bank dan } \\
\text { deposito }\end{array}$ & $1 \%$ & $1 \%$ & $1 \%$ & $1 \%$ & $0 \%$ & $1 \%$ \\
\hline $\begin{array}{l}\text { Aset tidak } \\
\text { lancar lain }\end{array}$ & $1 \%$ & $0 \%$ & $0 \%$ & $1 \%$ & $1 \%$ & $1 \%$ \\
\hline $\begin{array}{l}\text { Jumlah Aset } \\
\text { Tidak } \\
\text { Lancar }\end{array}$ & $86 \%$ & $93 \%$ & $92 \%$ & $93 \%$ & $92 \%$ & $92 \%$ \\
\hline \multicolumn{7}{|l|}{ ASET LANCAR } \\
\hline $\begin{array}{l}\text { Kas dan } \\
\text { setara kas }\end{array}$ & $4 \%$ & $2 \%$ & $3 \%$ & $3 \%$ & $2 \%$ & $3 \%$ \\
\hline $\begin{array}{l}\text { Pihak } \\
\text { Ketiga }\end{array}$ & $3 \%$ & $1 \%$ & $2 \%$ & $2 \%$ & $2 \%$ & $2 \%$ \\
\hline $\begin{array}{l}\text { Piutang } \\
\text { subsidi } \\
\text { listrik }\end{array}$ & $3 \%$ & $1 \%$ & $1 \%$ & $1 \%$ & $0 \%$ & $1 \%$ \\
\hline $\begin{array}{l}\text { Piutang } \\
\text { lain-lain }\end{array}$ & $0 \%$ & $0 \%$ & $0 \%$ & $0 \%$ & $1 \%$ & $0 \%$ \\
\hline Persediaan & $2 \%$ & $1 \%$ & $1 \%$ & $1 \%$ & $1 \%$ & $1 \%$ \\
\hline $\begin{array}{l}\text { Pajak bayar } \\
\text { dimuka }\end{array}$ & $1 \%$ & $0 \%$ & $0 \%$ & $0 \%$ & $0 \%$ & $1 \%$ \\
\hline $\begin{array}{l}\text { Jumlah aset } \\
\text { lancar }\end{array}$ & $14 \%$ & $6 \%$ & $8 \%$ & $7 \%$ & $8 \%$ & $8 \%$ \\
\hline $\begin{array}{l}\text { JUMLAH } \\
\text { ASET }\end{array}$ & $100 \%$ & $100 \%$ & $100 \%$ & $100 \%$ & $100 \%$ & $100 \%$ \\
\hline $\bar{X}$ & $23 \%$ & $27 \%$ & $23 \%$ & $23 \%$ & $23 \%$ & $23 \%$ \\
\hline
\end{tabular}

Sumber : Data diolah
Tabel 2 memberikan penjelasan jika nilai rata-rata analisis common size selama periode 2014-2018 untuk aset tetap yaitu sebesar $89 \%$, aset pajak tangguhan sebesar $1 \%$, rekeneing bank dan deposito berjangka yang penggunaanya di batasi sebesar $1 \%$, aset tidak lancar lain sebesar 1\%, jumlah aset tidak lancar sebesar 92\%, kas dan setara kas sebesar 3\%, pihak ketiga sebesar $2 \%$, piutang subsidi listrik $1 \%$, piutang lain-lain sebesar $0 \%$, persediaan sebesar $1 \%$, pajak bayar dimuka sebesar $1 \%$, jumlah aset lancar sebesar $8 \%$ dan jumlah aset sebesar $100 \%$ berdasarkan hasil tersebut maka diperoleh nilai ratarata analisis common size pada laporan neraca periode 2014-2018 sebesar 23\%.

Sebelum menghitung proyeksi neraca, kita harus mengetahui proyeksi total aset dimana untuk memperoleh hasil tersebut digunakan rumus yang sama dalam mencari pertumbuhan penjualan:

$$
\begin{aligned}
\mathrm{Gt} & =\frac{\mathrm{St}-\mathrm{S}_{\mathrm{t}-1}}{\mathrm{~S}_{\mathrm{t}-1}} \\
2015= & \frac{2015-(2015-2014)}{(2015-2014)} \\
& \frac{1,314,370,881-(1,314,370,881-607,448,324)}{(1,314,370,881-607,448,324)} \\
& \frac{1,314,370,881-(706,922,557)}{(706,922,557)} \\
& \frac{607,448,324}{706,922,557} \\
& 0.859
\end{aligned}
$$

Hasil dari formulasiperhitungan tersebutmemunculkan perolehan hasil untuk tahun:

$2015=0.859$

$2016=-31.151$

$2017=20.264$

$2018=8.474$

Kemudian untuk memperoleh tingkat pertumbuhan rata-rata digunakan perhitungan sebagai berikut:

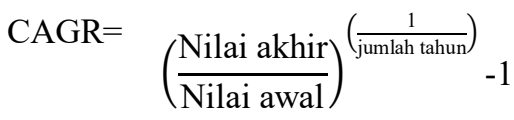




$$
\begin{aligned}
& \left(\frac{0.859}{8.474}\right)^{\left(\frac{1}{4}\right)}-1 \\
& (9.8649)^{(4)}-1 \\
& 1.7722-1 \\
& 0.7722 \text { atau } 77 \%
\end{aligned}
$$

Kemudian untuk memperoleh proyeksi laporan neraca digunakan perhitungan sebagai berikut:

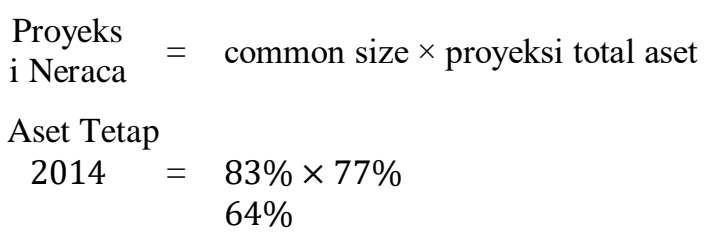

Hasil perhitungan tersebut digunakan rumus yang sama untuk tiap-tiap item dalam neraca untuk menentukan Financial Projecion (Proyeksi keuangan).Dinyatakan dalam hasil sebagai berikut:

\begin{tabular}{|c|c|c|c|c|c|c|}
\hline Catatan & 2014 & 2015 & 2016 & 2017 & 2018 & $\bar{X}$ \\
\hline \multicolumn{7}{|l|}{ ASET } \\
\hline \multicolumn{7}{|l|}{ ASET TIDAK } \\
\hline LANCAR & & & & & & \\
\hline aset tetap & $64 \%$ & $70 \%$ & $70 \%$ & $70 \%$ & $69 \%$ & $68 \%$ \\
\hline $\begin{array}{l}\text { Aset pajak } \\
\text { Tangguhan }\end{array}$ & $1 \%$ & $2 \%$ & $1 \%$ & $1 \%$ & $0 \%$ & $1 \%$ \\
\hline $\begin{array}{l}\text { Rekening } \\
\text { bank } \\
\text { dan } \\
\text { deposito }\end{array}$ & $1 \%$ & $1 \%$ & $0 \%$ & $0 \%$ & $0 \%$ & $0 \%$ \\
\hline $\begin{array}{l}\text { Aset tidak } \\
\text { lancar lain }\end{array}$ & $1 \%$ & $0 \%$ & $0 \%$ & $0 \%$ & $1 \%$ & $0 \%$ \\
\hline $\begin{array}{l}\text { Jumlah } \\
\text { Aset }\end{array}$ & & & & & & \\
\hline $\begin{array}{l}\text { Tidak } \\
\text { Lancar }\end{array}$ & $66 \%$ & $73 \%$ & $71 \%$ & $72 \%$ & $71 \%$ & $71 \%$ \\
\hline $\begin{array}{l}\text { ASET } \\
\text { LANCAR }\end{array}$ & & & & & & \\
\hline $\begin{array}{l}\text { Kas dan } \\
\text { setara kas }\end{array}$ & $3 \%$ & $1 \%$ & $3 \%$ & $2 \%$ & $2 \%$ & $2 \%$ \\
\hline $\begin{array}{l}\text { pihak } \\
\text { ketiga }\end{array}$ & $2 \%$ & $1 \%$ & $1 \%$ & $1 \%$ & $1 \%$ & $1 \%$ \\
\hline $\begin{array}{l}\text { Piutang } \\
\text { subsidi } \\
\text { listrik }\end{array}$ & $2 \%$ & $1 \%$ & $1 \%$ & $0 \%$ & $0 \%$ & $1 \%$ \\
\hline $\begin{array}{l}\text { Piutang } \\
\text { lain-lain }\end{array}$ & $0 \%$ & $0 \%$ & $0 \%$ & $0 \%$ & $0 \%$ & $0 \%$ \\
\hline Persediaan & $1 \%$ & $1 \%$ & $1 \%$ & $1 \%$ & $1 \%$ & $1 \%$ \\
\hline
\end{tabular}

\section{Tabel 3}

financial Projection Neraca 2014-2018

\begin{tabular}{lcccccc}
\hline Catatan & $\mathbf{2 0 1 4}$ & $\mathbf{2 0 1 5}$ & $\mathbf{2 0 1 6}$ & $\mathbf{2 0 1 7}$ & $\mathbf{2 0 1 8}$ & $\bar{X}$ \\
\hline $\begin{array}{c}\text { pajak bayar } \\
\text { dimuka }\end{array}$ & $1 \%$ & $0 \%$ & $0 \%$ & $0 \%$ & $0 \%$ & $0 \%$ \\
$\begin{array}{c}\text { jumlah aset } \\
\text { lancar }\end{array}$ & $11 \%$ & $5 \%$ & $6 \%$ & $5 \%$ & $6 \%$ & $7 \%$ \\
\hline $\begin{array}{c}\text { JUMLAH } \\
\text { ASET }\end{array}$ & $77 \%$ & $77 \%$ & $77 \%$ & $77 \%$ & $77 \%$ & $77 \%$ \\
$\bar{X}$ & $18 \%$ & $18 \%$ & $18 \%$ & $18 \%$ & $18 \%$ & $18 \%$ \\
\hline SUMber : Data diolah & & & &
\end{tabular}

Berdasarkanpada tabel 3 dapat dinyatakan hasil perhitungan financial projection (proyeksi keuangan) laporan neraca PT. PLN (Persero) tahun 20142018 diketahui:

\section{Aset Tetap}

Proyeksi pada aset tetap mengalami fluktuasi dimana nilai proyeksi mengalami peningkatan dari tahun 2014 sebesar 64\% hingga ditahun 2015-2017 dengan nilai yang sama sebesar $70 \%$ dan kembali menurun pada tahun 2018 sebesar 69\%. Sedangkan untuk nilai rata-rata proyeksi aset tetap dari tahun 2014-2018 sebesar 68\%.

\section{Aset Pajak Tangguhan}

Proyeksi pada aset pajak tangguhan mengalami fluktuasi dimana pada tahun 2014 nilai aset pajak tangguhan sebesar $1 \%$, kemudian pada tahun 2015 meningkat sebesar 2\%, kemudian menurun pada tahun 2016 sebesar $1 \%$ dan kembali menurun pada tahun2018 sebesar 0\%. Sedangkan untuk nilai rata-rata dari tahun 2014-2018 sebesar $1 \%$.

\section{Rekening Bank dan Deposito}

Pada proyeksi rekening bank dan deposito mengalami penurunan dimana nilai proyeksi pada tahun 2014-2015 sbesar $1 \%$. Mengalami penurunan dari tahun 2016-2018 sebesar 0\% atau tidak memiliki nilai proyeksi, rata-rata untuk nilai proyeksi selama tahun 2014-2018 sebesar $0 \%$.

\section{Aset Tidak lancar Lain}

Proyeksi pada aset tidak lancar lain mengalami fluktuasi dimana pada tahun 2014 nilai proyeksi pada aset tidak lancar sebesar $1 \%$ kemudian mengalami 
penurunan pada tahun 2015-2017 sebesar $0 \%$ dan kembali meningkat pada tahun 2018 sebesar 1\%. Sedangkan untuk rata-rata untuk nilai proyeksi selama periode 2014-2018 sebesar 0\%.

\section{Jumlah Aset Tidak Lancar}

Proyeksi pada jumlah aset tidak lancar juga mengalami fluktuasi dimana pada tahun 2014 nilai proyeksi sebesar $66 \%$, kemudian meningkat pada tahun 2015 sebesar $73 \%$, menurun pada tahun 2016 sebesar 71\%, meningkat pada tahun 2017 sebesar $72 \%$, dan kembali menurun pada tahun 2018 sebesar $71 \%$. Kemudian rata-rata untuk nilai proyeksi selama periode 2014-2018 sebesar 71\%.

\section{Kas dan Setara Kas}

Proyeksi padakas dan setara kas dinyatakan dengan nilai yang mengalami fluktuasi dimana pada tahun 2014 nilai proyeksi sebesar 3\%, menurun pada tahun 2015 sebesar 1\%, meningkat pada tahun 2016 sebesar 3\%. Dan kembali menurun pada tahun 2017-2018 dengan nilai yang sama sebesar $2 \%$. Sedangkan rata-rata untuk nilai proyeksi selama periode 2014-2018 sebesar 2\%.

\section{Pihak Ketiga}

Proyeksi padapihak ketiga mengalami penurunan dimana pada tahun 2014 nilai proyeksi sebesar 2\%, kemudian menurun pada tahun 20152018 yaitu dengan nilai proyeksi yang sama sebesar $1 \%$. Sedangkan rata-rata untuk nilai proyeksi selama periode 2014-2018 adalah sebesar $1 \%$.

\section{Piutang Subsidi Listrik}

Proyeksi pada piutang subsidi listrik mengalami penurunan dimana pada tahun 2014 nilai proyeksi sebesar $2 \%$, kemudian menurun pada tahun 2015-2016 sebesar 1\%, hingga tahun 2017-2018 nilai proyeksi terus menurun sebesar $0 \%$. Sedangkan rata-rata nilai proyeksi selama periode 2014-2018 sebesar $1 \%$.

\section{Piutang Lain-lain}

Proyeksi pada piutang lain-lain selama periode tahun 2014-2018 sebesar $0 \%$ atautidak memiliki nilai proyeksi.

\section{Persediaan}

Proyeksi persediaan selama periode 2014-2018 memiliki nilai yang sama sebesar $1 \%$. Sedangkan nilai ratarata untuk proyeksi persediaan selama periode 2014-2018 adalah sebesar 1\%.

\section{Pajak Bayar dimuka}

Proyeksi pada pajak bayar dimuka mengalami penurunan selama periode 2014-2018, dimana pada tahun 2014 sebesar 1\%, kemudian menurun tahun 2015-2018 yaitu sebesar 0\% atau tidak sama sekali. sehingga rata-rata untuk proyeksi selama 2014-2018 adalah $0 \%$.

\section{Jumlah Aset Lancar}

Proyeksi pada jumlah aset lancar mengalami fluktuasi dimana pada tahun 2014 nilai proyeksi sebesar $11 \%$, menurun pada tahun 2015 sebesar 5\%, meningkat pada tahun 2016 sebesar 6\%, lalu kembali menurun pada tahun 2017 sebesar 5\%, kemudian kembali meningkat pada tahun 2018 sebesar 6\%. Sehingga rata-rata untuk nilai proyeksi selama periode tahun 2014-2018 ialah sebesar $7 \%$.

\section{Jumlah Aset}

Proyeksi pada jumlah aset selama periode tahun 2014-2018 memiliki nilai yang sama yaitu sebesar $77 \%$. Sehingga rata-rata untuk nilai proyeksi selama periode tersebut ialah sebesar $77 \%$.

Berdasarkan dari pernyataan diatas diperoleh nilai rata-rata financial projection (proyeksi keuangan) pada laporan neraca periode 2014-2018 ialah $18 \%$, sehingga dapat dinyatakan financial projection (proyeksi keuangan) pada tahun mendatang mengalami peningkatan sebesar $18 \%$. 


\section{Laba Rugi}

Perhitungan analisis common size pada laporan neraca PT. PLN (Persero) adalah sebagai berikut:

laba rugi $=\quad\left(\frac{\text { item dalam laba rugi }}{\text { total penjualan }}\right) \times 100 \%$

Seperti halnya pada item penjualan tenaga listrik:

$$
\begin{aligned}
2014= & \left(\frac{186,634,484}{193,417,941}\right) \times 100 \% \\
& 96 \%
\end{aligned}
$$

Berdasarkan perhitungan tersebut digunakan rumus yang sama pada tiaptiap item dalam laba rugi untuk menentukan analisis common sizenya. Dinyatakan dalam hasil sebagai berikut:

\section{Tabel 4}

Laba Rugi Common Size 2014-

\begin{tabular}{|c|c|c|c|c|c|c|}
\hline Catatan & 2014 & 2015 & 2016 & 2017 & 2018 & $\bar{X}$ \\
\hline \multicolumn{7}{|l|}{$\begin{array}{l}\text { PENDAPATAN } \\
\text { USAHA }\end{array}$} \\
\hline $\begin{array}{l}\text { Penjualan } \\
\text { tenaga listrik }\end{array}$ & $96 \%$ & $97 \%$ & $96 \%$ & $97 \%$ & $97 \%$ & $97 \%$ \\
\hline $\begin{array}{l}\text { Biaya } \\
\text { penyambungan } \\
\text { pelanggan }\end{array}$ & $3 \%$ & $3 \%$ & $3 \%$ & $3 \%$ & $3 \%$ & $3 \%$ \\
\hline Lain-lain & $1 \%$ & $1 \%$ & $1 \%$ & $1 \%$ & $1 \%$ & $1 \%$ \\
\hline $\begin{array}{l}\text { Jumlah } \\
\text { Pendapatan } \\
\text { Usaha }\end{array}$ & $100 \%$ & $100 \%$ & $100 \%$ & $100 \%$ & $100 \%$ & $100 \%$ \\
\hline \multicolumn{7}{|l|}{ BEBAN USAHA } \\
\hline $\begin{array}{l}\text { Jumlah Beban } \\
\text { Usaha }\end{array}$ & $128 \%$ & $104 \%$ & $114 \%$ & $108 \%$ & $113 \%$ & $113 \%$ \\
\hline $\begin{array}{l}\text { RUGI USAHA } \\
\text { SEBELUM } \\
\text { PENDAPATAN } \\
\text { LAIN-LAIN }\end{array}$ & $-28 \%$ & $-4 \%$ & $-8 \%$ & $-13 \%$ & $-13 \%$ & $13 \%$ \\
\hline LABA USAHA & $23 \%$ & $22 \%$ & $12 \%$ & $10 \%$ & $8 \%$ & $15 \%$ \\
\hline $\begin{array}{l}\text { LABA (RUGI) } \\
\text { SEBELUM } \\
\text { PAJAK }\end{array}$ & $8 \%$ & $-7 \%$ & $6 \%$ & $3 \%$ & $7 \%$ & $3 \%$ \\
\hline $\begin{array}{l}\text { MANFAAT } \\
\text { (BEBAN) PAJAK }\end{array}$ & $-2 \%$ & $10 \%$ & $-2 \%$ & $-3 \%$ & $0 \%$ & $1 \%$ \\
\hline $\begin{array}{l}\text { LABA TAHUN } \\
\text { BERJALAN }\end{array}$ & $6 \%$ & $3 \%$ & $4 \%$ & $2 \%$ & $4 \%$ & $4 \%$ \\
\hline $\bar{X}$ & $23 \%$ & $33 \%$ & $33 \%$ & $31 \%$ & $32 \%$ & $32 \%$ \\
\hline
\end{tabular}
2018

Sumber : Data diolah

Tabel 5 menjelaskan bahwa nilai rata-rata proyeksi pada setiap item laba rugi selama periode tahun 2014-2015.
Pada item pendapatan usaha untuk biaya penjualan tenaga listrik nilai rata-rata sebesar $97 \%$, biaya penyambungan pelanggan sebesar 3\%, lain-lain sebesar $0 \%$, dan jumlah pendapatan usaha sebesar $100 \%$. Jumlah beban usaha sebesar $113 \%$, rugi usaha sebelum pendapatan lain-lain sebesar $-13 \%$, laba usaha sebesar $15 \%$, serta laba (rugi) sebelum pajak sebesar 3\%, manfaat (beban) pajak sebesar 1\% laba tahun berjalan sebesar $4 \%$. berdasarkan hasil tersebut maka diperoleh nilai rata-rata analisis common size pada laba rugi periode 2014-2018 sebesar 32\%.

Kemudian untuk memperoleh proyeksi laporan laba rugi digunakan perhitungan sebagai berikut:

Proyeksi laba rugi $=\quad\left(\frac{\text { item dalam laba rugi }}{\text { total penjualan }}\right) \times 100 \%$

Seperti halnya pada item penjualan tenaga listrik:

$$
\begin{aligned}
& 2014=\quad 96 \% \times 16 \% \\
& 16 \%
\end{aligned}
$$

Mengacu pada perhitungan tersebut digunakan rumus yang sama untuk tiap-tiap item dalam neraca untuk menentukan Financial Projecion (Proyeksi keuangan). Dinyatakan dalam hasil sebagai berikut:

\begin{tabular}{|c|c|c|c|c|c|c|}
\hline Catatan & 2014 & 2015 & 2016 & 2017 & 2018 & $\bar{X}$ \\
\hline \multicolumn{7}{|l|}{$\begin{array}{l}\text { PENDAPATAN } \\
\text { USAHA }\end{array}$} \\
\hline $\begin{array}{l}\text { Penjualan } \\
\text { tenaga listrik }\end{array}$ & $16 \%$ & $16 \%$ & $15 \%$ & $16 \%$ & $16 \%$ & $16 \%$ \\
\hline $\begin{array}{l}\text { Biaya } \\
\text { penyambunga } \\
\text { n pelanggan }\end{array}$ & $0 \%$ & $0 \%$ & $1 \%$ & $0 \%$ & $0 \%$ & $0 \%$ \\
\hline Lain-lain & $0 \%$ & $0 \%$ & $0 \%$ & $0 \%$ & $0 \%$ & $0 \%$ \\
\hline $\begin{array}{l}\text { Jumlah } \\
\text { Pendapatan } \\
\text { Usaha }\end{array}$ & $16 \%$ & $16 \%$ & $16 \%$ & $16 \%$ & $16 \%$ & $16 \%$ \\
\hline \multicolumn{7}{|l|}{ BEBAN USAHA } \\
\hline $\begin{array}{l}\text { Jumlah Beban } \\
\text { Usaha }\end{array}$ & $21 \%$ & $17 \%$ & $18 \%$ & $17 \%$ & $18 \%$ & $18 \%$ \\
\hline $\begin{array}{l}\text { RUGI USAHA } \\
\text { SEBELUM }\end{array}$ & $-5 \%$ & $-1 \%$ & $-2 \%$ & $-1 \%$ & $-2 \%$ & $-2 \%$ \\
\hline
\end{tabular}

\section{Tabel 5}

Financial projection Laba Rugi 2014-2018 


\begin{tabular}{lcccccc}
\hline \multicolumn{1}{c}{ Catatan } & 2014 & 2015 & 2016 & 2017 & 2018 & $\bar{X}$ \\
\hline $\begin{array}{l}\text { PENDAPATAN } \\
\text { LAIN-LAIN }\end{array}$ & & & & & & \\
\hline LABA USAHA & $4 \%$ & $4 \%$ & $2 \%$ & $2 \%$ & $1 \%$ & $3 \%$ \\
\hline $\begin{array}{l}\text { LABA (RUGI) } \\
\text { SEBELUM } \\
\text { PAJAK }\end{array}$ & $1 \%$ & $-1 \%$ & $1 \%$ & $1 \%$ & $1 \%$ & $1 \%$ \\
\hline $\begin{array}{l}\text { MANFAAT } \\
\text { (BEBAN) } \\
\text { PAJAK }\end{array}$ & $0 \%$ & $2 \%$ & $0 \%$ & $0 \%$ & $0 \%$ & $0 \%$ \\
\hline $\begin{array}{l}\text { LABA TAHUN } \\
\text { BERJALAN }\end{array}$ & $1 \%$ & $0 \%$ & $1 \%$ & $0 \%$ & $1 \%$ & $1 \%$ \\
\hline $\bar{X}$ & $5 \%$ & $5 \%$ & $5 \%$ & $5 \%$ & $5 \%$ & $5 \%$ \\
\hline
\end{tabular}

Sumber : Data diolah

Berdasarkan tabel diatas dapat dinyatakan hasil perhitungan financial projection (proyeksi keuangan) laporan laba rugi PT. PLN (Persero) tahun 20142018 diketahui:

\section{Penjualan Tenaga Listrik}

Proyeksi pada penjualan tenaga listrik pada tahun 2014-2015 memimiliki nilai yang sama yaitu sebesar $16 \%$, kemudian menurun pada tahun 2016 sebesar $15 \%$, dan kembali meningkat pada tahun 2017-2018 sebesar 16\%. Sehingga untuk nilai rata-rata proyeksi selama periode 2014-2018 ialah sebesar $16 \%$.

\section{Biaya Penyambungan Pelanggan}

Proyeksi pada biaya penyambungan pelanggan pada tahun 2014-2015 adalah 0\% atau tidak ada, kemudian meningkat pda tahun 2016 sebesar $1 \%$ dan kembali menurun pada tahu 2017-2018 dengan nilai yang sama yaitu $0 \%$, sehingga nilai rata-rata proyeksi selama periode 2014-2018 ialah $0 \%$.

\section{Lain-lain}

Proyeksi pada lain-lain selama periode 2014-2018 ialah 0\% atau sama sekali tidak ada, sehingga nilai rata-rata proyeksi selama periode 2014-2018 ialah $0 \%$.

\section{Jumlah pendapatan Usaha}

Proyeksi pada jumlah pendapatan usaha selama periode tahun 2014-2018 memiliki nilai yang sama yaitu sebesar $16 \%$, sehingga nilai ratarata proyeksi selama periode 2014-2018 ialah $16 \%$.

\section{Jumlah Beban Usaha}

Proyeksi pada jumlah beban usaha mengalami fluktuasi dimana pada tahun 2014 nilai proyeksi sebesar $21 \%$, kemudian menurun pada tahun 2015 sebesar $17 \%$, meningkat pada tahun 2016 sebesar $18 \%$, menurun pada tahun 2017 sebesar $17 \%$ dan kembali meningkat pada tahun 2018 yaitu sebesar $18 \%$, sehingga nilai rata-rata proyeksi selama periode 2014-2018 ialah 18\%.

\section{Rugi Usaha Sebelum Pendapatan Lain-lain}

Proyeksi pada rugi usaha sebelum pendapatan lain-lain bernilai negatif yaitu pada tahun 2014 sebesar 5\%, tahun 2015 sebesar $-1 \%$, tahun 2016 sebesar -2\%, tahun 2017 sebesar -1\% dan pada tahun 2018 ialah sebesar $-2 \%$, sehingga nilai rata-rata proyeksi selama periode 2014-2018 ialah -2\%.

\section{Laba Usaha}

Proyeksi pada laba usaha selama periode 2014-2018 mengalami penurunan dimana pada tahun 20142015 nilai proyeksi sebesar 4\%, kemudian terus menurun dari tahun 2016-2017 sebesar 2\%, dan sebesar 1\% untuk tahun 2018. sehingga nilai ratarata proyeksi selama periode 2014-2018 ialah $3 \%$.

\section{Laba (Rugi) Sebelum Pajak}

Proyeksi pada laba (rugi) sebelum pajak selama periode 20142018 memiliki nilai yang sama yaitu sebesar 1\%, kecuali pada tahun 2015 yang mengalami penurunan sebesar $-1 \%$ namun kembali meningkat pada tahun 2016-2018 dengan nilai yang sama sebesar $1 \%$. sehingga nilai rata-rata proyeksi selama periode 2014-2018 ialah $1 \%$.

\section{Manfaat (Beban) Pajak}

Proyeksi pada manfaat (beban) pajak selama periode 2014-2018 memiliki nilai yang sama yaitu sebesar 
$0 \%$ atau tidak ada, kecuali pada tahun 2015 yang sempat mengalami peningkatan sebesar $-2 \%$ namun kembali menurun pada tahun 2016-2018 dengan nilai yang sama sebesar $0 \%$. sehingga nilai rata-rata proyeksi selama periode 2014-2018 ialah 0\%.

\section{Laba Tahun Berjalan}

Proyeksi pada laba tahun berjalan mengalami fluktuasi. Dimana pada tahun 2014 nilai proyeksi sebesar 1\%, kemudian menurun pada tahun 2015 sebesar $0 \%$, kemudian meningkat pada tahun 2016 sebesar 1\%, menurun pada tahun 2017 sbesar 0\% dan kembali meningkat pada tahun 2018 sebesar $1 \%$. sehingga nilai rata-rata proyeksi selama periode 2014-2018 ialah 1\%.

Berdasarkan dari pernyataan diatas diperoleh nilai rata-rata financial projection (proyeksi keuangan) pada laporan laba rugi periode 2014-2018 ialah 5\%, sehingga dapat dinyatakan financial projection (proyeksi keuangan) pada tahun mendatang mengalami peningkatan sebesar $5 \%$.

Berdasarkan hasil penelitian yang telah dijabarkan financial projection pada pertumbuhan penjualan, laporan neraca dan laba rugi selama periode 2014-2018 pada laporan keuangan diperoleh hasil yang meningkat dengan demikian financial projection dapat digunakan sebagai strategi pengelolaan keuangan pada PT. PLN (Persero) guna untuk memprediksi segala keuntungan dan kerugian yang dapat terjadi di masa yang akan datang serta dapat pula mengantisipasi segala perubahan yang akan terjadi untuk beberapa tahun mendatang.

\section{SIMPULAN}

Berdasarkan hasil penelitian dan pembahasan yang telah dijabarkan maka dapat disimpulkan, financial projection pada pertumbuhan penjualan selama periode tahun 2014-2018 mengalami peningkatan sebesar $16 \%$ sehingga dapatdigunakan sebagai proyeksi dimasa yang akan datang.Financial projection pada laporan neraca selama periode 2014-2018 mengalami peningkatan sebesar $18 \%$ sehingga dapat digunakan sebagai proyeksi dimasa yang akan datang.

Financial projection pada laporan laba rugi selama periode 20142018 mengalami peningkatan sebesar 5\% sehingga dapat digunakan sebagai proyeksi dimasa yang akan datang.Financial projection dapat digunakan sebagai strategi pengelolaan keuangan pada PT. PLN (Persero) guna untuk memprediksi segala keuntungan dan kerugian yang dapat terjadi di masa yang akan datang serta dapat pula mengantisipasi segala perubahan yang akan terjadi untuk beberapa tahun mendatang.

Sebaiknya perusahaan menggunakan analisis financial projection sebagai salah satu strategi yang dapat digunakan dalam mengelola perusahaannya agar dapat mengantisipasi segala kerugian serta perubahan-perubahan yang dapat terjadi untuk beberapa tahun mendatang.Peneliti selanjutnya, diharapkan penelitian ini dapat menjadi bahan referensi dalam mengembangkan model penelitian ini di masa yang akan datang dengan menambah jumlah laporan keuangan perusahaan untuk dianalisis agar dapat lebih akurat serta dapat pula mencari metode-metode lain untuk menghitung financial projection (proyeksi keuangan) pada perusahaan yang ingin di teliti.

\section{DAFTAR PUSTAKA}

Anjasmara, W. F. (2012). Proyeksi Laporan Keuangan Perusahaan Rokok Oeloeng Bojonegoro. (Doctoral dissertation, University of Muhammadiyah Malang).

Arifin, M. N. (2018). Analisis Peramalan Keuangan Pada 
Koperasi Pegawai Republik Indonesia (KPRI) Di Kecamatan Nguling Kabupaten Pasuruan Tahun $2018 \quad$ (Doctoral dissertation, University of Muhammadiyah Malang).

Brigham, Eugene $\mathrm{F}$ dan Houston. (2006). Fundamental of FinancialManagement: DasarDasar Manajemen Keuangan. Edisi 10. Jakarta: Salemba Empat.

Enda, N. N. E. (2013). Implementasi Financial Projection Sebagai Strategi Pengelolaan Keuangan Perusahaan Daerah Air Minum Surya Sembada Kota Surabaya (Doctoral dissertation, STIE Perbanas Surabaya).

Farida, I., Suharti, T., \& Yudhawati, D. (2019). Analisis Metode Common Size Untuk Mengukur Kinerja Keuangan Pada Perusahaan. Manager: Jurnal Ilmu Manajemen, 2(2), 55-79.

Gumanti, T. A. (2015). Teori Sinyal Dalam Manajemen Keuangan Korporasi.

Heizer, Jay and Barry Rander. (2015). Manajemen Operasi, Manajemen Keberlangsungan dan Rantai Pasokan, Edisi 11, Alih Bahasa : Hirson Kurnia, Ratna Saraswati dan David Wijaya, Penerbit Salemba Empat, Jakarta.

Kasmir. (2012). Analisis Laporan Keuangan. Jakarta: PT Rajagrafindo Persada.

Kasmir. (2015). Analisis Laporan Keuangan. (Edisi 8). Cetakan ke VIII. Jakarta: PT Rajagrafindo Persada.

Rianti, M. N. (2014). Analisis Laporan Keuangan Proforma Sebagai Dasar Proyeksi Kinerja Keuangan Pada PT Garam (Persero) Surabaya (Doctoral dissertation, University of Muhammadiyah Malang).
Rizky, F. N. N., Wasito, S. E., \& MSIE, P. I. (2019). Analisis Peramalan Penjualan Dalam Rangka Menentukan Perencanaan Produksi Sepatu Kulit Pada PT. Brodo Ganesha Indonesia (Doctoral dissertation, Perpustakaan Fakultas Ekonomi dan Bisnis Unpas).

Sudana, I. M. (2015). Teori dan Praktik Manajemen Keuangan Perusahaan (Edisi 2). Jakarta : Erlangga.

Sugiyono. (2014). Metodologi Penelitian Bisnis (Pendekatan Kuantitatif, Kualitatif), Cetakan ke-18, Alfabeta. Bandung.

Sugiyono. (ARA2017). Metode Penelitian Kuantitatif, Kualitatif, dan R\&D. Bandung : Alfabeta, CV.

Susanto, A. (2013) Teori Belajar dan Pembelajaran di Sekolah Dasar. Jakarta: Kencana Premedia Group.

Syafitri, E. (2014). Analisa Penilaian Persediaan Batu Bara dengan Metode Fifo dan Average Serta Dampaknya Terhadap Laporan Laba Rugi Pada Apt Bumi Merapi Energy. Stie Mulia Darma Pratama.

Wulandari, I. (2016). Proyeksi Laporan Keuangan PT Bukit Asam (Persero) TBK. Tanjung Enim Tahun 2015-2020. Bandar Lampung : Fakultas Ekonomi dan Bisnis Universitas Lampung

Zamaro, R. T. (2018). Analisis Penghitungan Proyeksi Belanja Operasional Kementrian Negara Dan Lembaga Untuk Penyusunan Pagu Indikatif. Jurnal Anggaran dan Keuangan Negara Indonesia (AKURASI), 2(2), 14-14. 